\title{
The Use of Social Media Bot Accounts on Influencing Public Opinion: A Legal Review in Indonesia
}

\author{
Devi Rahma Fatmala ${ }^{1 *}$, Amanda Amelia ${ }^{2}$, Fitri Agustina Trianingsih ${ }^{2}$ \\ 1,2,3 Master of Laws, Faculty of Law, University of Airlangga, Surabaya, East Java, 60286, Indonesia \\ * Corresponding author: devirahmafatmala11@gmail.com

\begin{tabular}{ll}
\hline Article & Abstract \\
\hline Keywords: & $\begin{array}{l}\text { Today's political discourse cannot be separated from the usage of social media. } \\
\text { Bot accounts; social media; } \\
\text { public opinion; democracy; } \\
\text { their political rivals to influence public opinion. One of the instruments used by } \\
\text { the political actor in using social media is bot accounts. Bot accounts are an } \\
\text { automated online account where all or substantially all of the actions or posts of } \\
\text { that account are not the result of a person. The usage of bot accounts is viewed as }\end{array}$ \\
$\begin{array}{l}\text { Article History } \\
\text { Received: May 8,2020; } \\
\text { Reviewed: June 3,2020; for democracy by many experts on law and democracy. However, lots of } \\
\text { Accepted: Sept 14,2020; }\end{array}$ & $\begin{array}{l}\text { This article intends to bring legal review on the usage of bot accounts to influence } \\
\text { public opinion in Indonesia. By using deliberative democratic theory, this article } \\
\text { viens that the usage of bot accounts could prevent the objective achievement of } \\
\text { democracy based on the 1945 Constitution. The authors recommend the } \\
\text { regulation of bot accounts through the revision of Law Number 11 of 2008 } \\
\text { concerning Electronic Information and Transactions with bringing up various } \\
\text { notable arguments regarding the law implementation. }\end{array}$ \\
DOI: 30,2020 & \\
10.22219/ljih.v28i2.12148
\end{tabular}

(C)2020; This is an Open Access Research distributed under the term of the Creative Commons Attribution License (https://Creativecommons.org/licences/by/4.0), which permits unrestricted use, distribution, and reproduction in any medium, provided the original works is properly cited.

\section{INTRODUCTION}

The political discourse is an essential aspect of a nation's democratic life. It is necessary because through its existence the problems relating to the placement and management of power are discussed, debated, and clashed. Through a lively political discourse, starting from the planning process and policy implementation are being debated and the monitoring mechanism is ongoing. In addition, who is entitled and not entitled to hold particular positions, what words are worthy or unworthy to say, and what actions are appropriate or improper to take are still debatable. Therefore, in a democratic nation, the life of political discourse becomes one of the benchmarks 
for the accountability of its government and the independence of the freedom of expression of its people (Madison, 2017).

In today's context, the political discourse process cannot be segregated from the existence of social media. Social media, as part of the information and communication technology development closely related to the Internet, has become a medium for citizens not only to voice their opinions but also to broaden their political views to gather collective strength. With the low cost of engaging in it, social media attracts more people to participate in political discourse. This fact has made social media rated as a medium with positive potential that is proven to have a major influence behind massive collective movements such as the Arab Spring or Occupy Wall Street (Madison, 2017).

Nevertheless, like any other media, some media platforms can pose a threat to democracy (Al-Fatih, Aditya, Haris, \& Kurniawan, 2019). Many researchers highlight various phenomena that are assessed to lower the quality of democratic life in a nation (Tucker et al., 2018). These phenomena are categorized into two of the most common phenomena, namely political polarization and disinformation. Political polarization is the condemnation of a political situation as if the existing political conditions only have two strongholds with opposite positions. The opposing stronghold is often portrayed as a party with negative and extreme traits that must be repressed as hard as possible so as not to dominate political discourse (Soebakir, Pratama, \& Hair, 2020; Tucker et al., 2018). Moreover, disinformation in a broad sense refers to the dissemination of incorrect information and in a particular sense is the dissemination of information that has a factual basis packaged in a certain way to obscure from the initial contextual foundation of the information into a new contextual based on the political interests of the information disseminators (Tucker et al., 2018).

Two things and some of the following phenomena occur globally, including in Indonesia. Political polarization and disinformation can at least be seen since the election of the Governor of DKI Jakarta in 2012. With 129.2 million active social media users (Ansari et al., 2016), social media in Indonesia has become one of the many media of political discourse filled with polarization and disinformation. This polarization and disinformation process is widely disseminated to wage cyberwar. Cyberwar itself in the context of social media is a clash of discourses to gain a dominant position in political discourse through various instruments, from the spread of propaganda to attacks on personalities aiming to hit the psychological condition of the opponent or get support from the wider community (Firmansyah, Mulyana, Karlinah, \& Sumartias, 2018).

One context that has occurred in the cyberwar was the cyberwar between JASMEV (Jokowi Ahok Social Media Volunteers) that also known as the political 
volunteer organization for the winning of both Joko Widodo and Basuki Tjahya Purnama as Governor and Deputy Governor of DKI Jakarta in 2012-2017 with a conservative Muslim group which at that time has not been harmonized under the one umbrella. Furthermore, in 2014 there was also a cyberwar occurred between the supporters of Joko Widodo and Jusuf Kalla (who were mostly advocated by JASMEV) and the supporters of Prabowo Subianto and Hatta Rajasa who were coordinated under many umbrellas, but in general their profile was conservative Muslims (Nurul, Nurhadi, \& Pranawa, 2020; Syahputra, 2017).

The number of cyberwars that occur on social media involves various models of hate speech against the opposing group. This hate speech is then sharpened the polarization that occurs. Polarization is considered as a mass-raising instrument that is pragmatically capable of producing fanatical volunteers or commonly called hearers who are willing to defend their friends regardless of their true absence. In addition, because hate speech is more capable to harvest public emotions, it is mostly presented in the form of disinformation and is not often followed by pressure or intubation (Firmansyah et al., 2018; Syahputra, 2017). Worse, this cyberwar cannot be performed effectively by people who already have high positions in the Indonesian Government both in the executive and legislative branches; because they need to maintain a good image in the eyes of public for the electability of their voice. On the other hand, volunteers who want to get a promotion must also be cautious about using their real identities so they do not become contradictory digital traces in the future. This need brings out many anonymous accounts and the main discussion in this paper, bot accounts.

Many bot accounts (robot accounts) function as a point of view to be featured, usually in the form of a hashtag. In addition, it also serves to attack not only the argument but also the opponent's personality in the crowd to delegate the opponent's voice. This fact makes interactions in political discourse on social media completely non-organic controlled by humans with responsible institutions (Arianto, 2020). Therefore, many observers of law and democracy consider the existence of this bot account lowers the quality of democracy. In addition, the forces of disinformation spreading and polarization dissemination, the existence of bot accounts make counterproductive voice accountability unclear. Moreover, the outcomes of the engineering public opinion with the bot account also make something that is widely discussed through social media not only for public restlessness, but there is piracy there that can harm the public interest itself (Arianto, 2020).

Although there are potential downsides from the existence of bot accounts for political and democratic discourses in Indonesia, until now there has not been a strong discussion in the legal context of how bot accounts are positioned in Indonesian law. Given that the lack of legal study about bot accounts in Indonesia, 
the authors hope that this paper can open a juridical discussion in the future regarding the legal status of bot accounts. Everything is aimed for a better democratic life in Indonesia.

The fundamental question to be answered in this paper is what the position of bot accounts in Indonesian law is. Through this fundamental question, derivative questions arise such as (1) how the philosophical reviews of political and legal experts about bot accounts are and (2) legal instruments in Indonesia that can be used to manage bot legal accounts.

Therefore, this research article undertakes a legal exploration of bot accounts as well as to review and provide recommendations on how the bot accounts are positioned in Indonesian law. This article is divided into four sections, namely the introduction, research methodology, results \& discussion, as well as conclusions. The introductory section contains background issues, research objectives, and research questions. Meanwhile, the preliminary section ends with an explanation of the sharing of this writing.

As mentioned above, although the problem seems obvious, there has been no research on the use of bot accounts in Indonesia. Thus, the contribution of this research will be a starter for more elements of society to take bot accounts and their relationship with democratic life in Indonesia more seriously, especially regarding legal matters.

\section{METHOD}

The normative legal research method is used in writing this article. This methodology views law as something that must be applied collectively in the society. Therefore, the normative method departs from unnecessary assumptions about the values that need to be applied collectively, then sees whether there is any legal product that can be interpreted to conform to these values (Hage, 2011). Moreover, the approach used in this normative legal research is the conceptual approach as what Marzuki stated in 2010. In a conceptual approach, this research will discuss about the developed concepts and how law scholars defined those concepts and relate them to other concepts. As normative legal research on the use of bot accounts in democracy, this research will advance the aspects of democracy that must be fulfilled so that democratic life and the state will be more accountable by using deliberative democratic theories as a further framework. Afterward, the argumentation on the existence of bot accounts whether or not it damages democracy following a structured framework will be discussed.

Furthermore, what arguments or considerations need to be considered or need to be avoided in implementing the law concerning bot accounts will be put in order so as not to violate the democratic function that has been previously deployed. In 
connection with the absence of research or legal cases in Indonesia related to bot accounts, this research does not use existing legal products as the primary source. This research relies on secondary sources in the form of foreign legal research on bot accounts and non-legal research such as from the political science discipline regarding the relationship between bot accounts and democracy as data source of to be analysed and outlined. The data are then analysed interpretatively and elaborated to answer the fundamental research questions and their derivatives described at the end of the introduction.

\section{RESULTS AND DISCUSSION Deliberative Democracy}

Democracy is an abstract concept related to how power should be regulated in a power management apparatus such as the state. Democracy generally puts the power in the hands of the people because it is present as the antithesis of authoritarianism that focuses authority on the main leaders, such as the President or King. As an abstract concept, the operationalization of democracy varies greatly depending on how each expert gets in the way. However, there is still a common thread in the aspect of democracy that is considered to exist in the nation-state. Five broadly agreed criteria as characteristics of democracy, i.e. (1) effective participation in the sense of every citizen has equal access and opportunity to speak up to influence the outcome of a decision, (2) equality in voting meaning that every citizen need to have equal weight in elections, (3) a deep understanding of every citizen must have the same opportunity to transparently know about the impact of public decisions on them, (4) control over the agenda meaning that citizens have the opportunity to understand how an issue can be positioned as a political agenda, and (5) inclusiveness meaning that the entire democratic process must include all citizens without exception (Dahl, 1991).

This criterion was then further developed by deliberative democracy theory. One of the thoughts was stated by Karlsson (2003) that the core of the democratic process lies in the stages before political decision-making, especially on the discussion process to bring forth a political decision. The deliberative process of democracy involves political actors who communicate based on rational arguments to change and shape the preferences of the other party. Therefore, three aspects need to be recognized first to identify how deliberative a democratic process is. The first aspect is who is speaking, the second aspect is how many political actors are involved in the conversation, and the third aspect is where the discussion or conversation takes place. In the first aspect, the deliberative democratic process can occur between citizens, representatives of a population group, or between citizens and representatives themselves. In the second aspect, one of the things that needs to be observed is how the discussion process between representatives is, because not every 
conversation can be said to be an indirect deliberation for citizens. In the third aspect, it is necessary to explain beforehand that the essence of the deliberation process is to reflect rationally on the objectives of political action and the ways that can bring the best outcomes. Previously, the private area was often not considered as part of deliberative democracy. Meanwhile, with the internet development nowadays, the private area is expanding and people can be involved in the deliberations process more easily. On the other hand, discussions that take place in traditional public spaces such as physical public spaces and mass media often place unconscious political codes that must be ignored on matters that are part of the fidgetiness but do not arise because they are not worthy to discuss (Karlsson 2003).

Apart from Karlsson, Fishkin (2014) also strengthens the democratic aspects of deliberation into five criteria derived from two fundamental aspects of deliberative democracy, namely inclusivity and full awareness. The first criterion is the distribution of accurate information, which will be fulfilled if each participant in the deliberations process has been provided with all the necessary information to select the position chosen through their consideration. The second criterion is the balance of substance that is achieved when one party's argument is answered with consideration of the other parties who has different viewpoints. The third criterion is the diversity that is fulfilled with all political positions in society having to have a representative in the deliberations process. There is no rational opinion that can be eliminated just because of differences in identity and each position of identity must have the same proportion of space so that it is not weighted in one side. The fourth criterion is awareness that is filled with the arguments presented, which are then discussed and judged according to the quality of the arguments. Next is equal consideration. This fifth criterion is fulfilled when the arguments are assessed from the side of the argument itself, not from whose side (Fishkin 2014).

Is this deliberative democracy desirable in Indonesia? According to Halim's interpretation (2016) on Article 1 Paragraph (2) and (3) of the 1945 Constitution (Indonesian Constitution), people's sovereignty needs to be widely distributed not only to the state authority institutions, but also to be applied to the processes within these institutions. Therefore, all political decision-making processes in it must undergo the transparent, accountable, and inclusive processes that are all part of the deliberative democracy characteristics.

Apart from that, the theory of democracy in Indonesia that is based on Pancasila has developed, which was later referred as Pancasila Democracy. The authors view that there are lots of similarities between Pancasila Democracy and deliberative democracy. For instance, Kuntowijoyo (in Cholisin 2013) stated that democracy will only be achieved if (1) the people are above the state in distribution 
of power, (2) the social welfare of the people is fulfilled, and (3) the productive forces are distributed to the society. Cholisin (2013) also stated that there are several principles of Pancasila Democracy. These principles are: (1) equality among Indonesian citizens; (2) the equal weight of rights and obligations; (3) giving freedom with responsibility to God, oneself, and others; (4) fulfilling social justice; and (5) formulating decisions in rational discussions (musyawarab) with fairness. This concept is pretty much similar to the deliberative democracy concept presented above. However, since deliberative democracy is a more well-developed concept and theory, it is used here to analyze the problem.

\section{Bot Accounts Definition}

Bot accounts are accounts in social media that are controlled by both content and behavior by particular software programs. On social media, bot accounts are not flagged as social media bots. As a result, bot accounts are often mistaken as real people's social media accounts. In 2017, there were researches conducted by the University of Southern California and Indiana University which estimated that 9-15\% of Twitter users were bot accounts with an increasing number over time (Athallah, 2019). In Indonesia, no research has provided an estimate of the number of bot accounts, but one of the research outcomes by the Drone Emprit agency (Fahmi, 2019) shows the number of tweets from bot accounts engaged in a hashtag war (part of cyberwar) on Twitter in the lead up to the 2019 presidential election. In the hashtag's war, the two hashtags had a low engagement rate with the highest of $1.76 \%$, meaning that many tweets were not getting likes or retweets. That outcome is a heavy indication that the account was a bot account, with dominance of accounts with no more than 500 followers that made in the same month. With a total of over 30,000 tweets across both hashtags, there are at least 13,000 tweets generated by bot accounts.

Actually, from a little overview of this bot account, it can be seen how the bot account distorts voices on social media so that it seems as if many are talking about it or even worse it is perceived as a public voice. Furthermore, technological developments allow bot accounts to develop better in resembling humans. Using software algorithms that allow bot accounts to perform machine learning, bot accounts can read even more social media contents than any human being as they can be active 24 hours non-stop. The more sophisticated the bot account in the capability of imitating human behavior, the more valued it is in the buzzer industry (Lee, 2019; Nurul et al., 2020). However, it should be noted that a bot account is a tool not only used for political propaganda, but can also be used for purposes purely for entertainment matters, such as sharing a poem daily, linking between news sites and social media using bots that can upload any life update, or share other factual information. 


\section{Bot Account as a Barrier for the Actualization of Deliberative Democracy}

Although the nature of bot account instruments is neutral, it is evident that their use in the hearing industry is primarily aimed at cyber warfare which sharpens polarization and disinformation. In the Oxford Internet Institute's research (Bradshaw \& Howard, 2019), it was explained that the majority of Indonesian buzzer industry is using cyber troops with small capacities that are only active when election time approaches and because of this small capacity end up relying on the bot accounts to amplify certain messages through disinformation. According to both, these bot accounts were used to spread messages to support a stronghold, to attack opposition parties, and to sharpen disputes between parties. One study (Ferrara, Varol, Davis, Menczer, \& Flammini, 2016) visualized conversations on Twitter in the context of implementing California's vaccination laws. In visualization, there are many points and each point representing a Twitter account. Each point has a size, the bigger the account, the greater interaction and impact gained. There are three colors at the dots. The red dots indicate bots, the blue dots indicate human accounts, and the purple dots indicating difficulty in determining whether the account is a bot or not. The lines connecting the dots represent the interactions between these dots. The visualization is shown in the picture below.

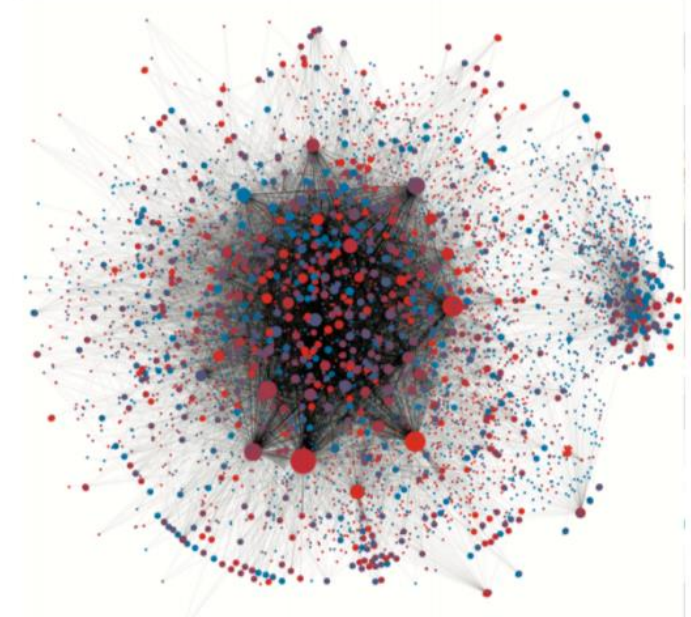

Figure 1. Cyber War on Twitter Visualization (Ferrara et al. 2016)

Through the visualization above, the color red can be seen dominating the conversation both in large and small sizes. This certainly makes it true that the dominant conversations on Twitter in this particular context as well as on social media in the same context are raised by humans with genuine agencies who want the deliberations process to occur. The use of a bot account that is controlled by a group of people only makes the circle grow and makes other smaller circles increasingly lacking or even lose the opportunity to voice their opinions on the issue at hand. 
It should be noted that in general there are two patterns of information dissemination, namely linear and exponential patterns. In the case of the 2017 DKI Jakarta governor election, the target pattern for information disseminating is an exponential pattern. To activate this exponential pattern, normal and organic methods used in achieving societal outreach are ineffective. Therefore, bot accounts are widely used to ensure that the information is shared exponentially. This has led to the many trending hashtags on Twitter related to the Jakarta governor election and all of them were greatly assisted by bot accounts (Abdulsalam 2018).

In an exponential pattern, it is expected that one dot of disseminated information will convey information to two other new dots. So that on the thirtieth day it could reach 2 billion people. Although this number is not ideal to be achieved, the actual number is still much more than 30 people on the $30^{\text {th }}$ day, assuming one dot of information dissemination only spreads to other dots. Therefore, people who already have political positions in the 2017 Jakarta gubernatorial election will be lacking of similar information and only few people who try to voice rationality will be driven from the stream of the discourse (Lim 2017).

As previously explained, the existence of bot accounts hurt is detrimental to the democratic deliberation process from various sides. The first side is a bot account that manipulates the public talks so that which is not actually what the public wants, but that one party having access to the account's use is wanted. In the context of Indonesia, as reflected in Fahmi's research (2019), it can be seen that the presence of listeners with their bot accounts makes it seems as if they are only divided into two parties. Meanwhile, if the account factor is removed, the discussion will be richer and it will not only be found that two parties in very opposite positions. Furthermore, the existence of bot accounts multiplies the propagation of disinformation. Since the goal is to sharpen political fanaticism, one of the easiest ways to achieve this is with an emotional harvest load that alludes to the aspects of its identity. Therefore, disinformation becomes a widely used tool because it is considered relatively easier to harvest emotional aspects. It certainly violates the aspects of information desired in a deliberative democracy. The information shared by bot accounts that are supported by existing social media algorithms means that people only receive partial information that is similar to their preferences and values. Therefore, the reality is not intact, and it is as if the activities of the opposing party always make them lose and be threatened (Hellden \& Gulliksen, 2017; Zainal \& Megasari, 2019).

Hereinafter, the existence of bot accounts also substantially imbalanced the interactions between warring parties. In that sense, the answer to a party's proposition is not processed in advance according to its consideration, but the undisputed raw is either true or false. This is reflected in the release made by Athallah 
(2019) which shows that in the trial industry one of the things that abstinence is to admit defeat in debates. Because of this, bot accounts are often developed to launch verbal attacks in the form of ridicule and insults to delegate the opinion of the opposing party. Then, the existence of these bot accounts also undermines the diversity aspect in deliberative democracy. The use of bot accounts displaces many votes that do not have access to bot accounts. As the result, groups with minority identities will be neglected in the deliberations process. With the existence of bot accounts, opinions that arise and develop are only limited to two extreme positions. Diversity restrictions also apply to the availability of position options and criticism from parties who do not have an equal position, as if not a position that means unilaterally with the competitor but it does not have to be (Hellden \& Gulliksen 2017).

\section{Consideration on Where to Place Bot Account in Indonesian Law}

Given the potential threat posed by bot accounts for democratic life in Indonesia, it is necessary to include the discussion of bot accounts in Indonesian legal products. As previously mentioned, Article 1 Paragraph (2) and (3) of the 1945 Constitution are in line with the characteristics desired by deliberative democracy. Therefore, one of the mandates of the 1945 Constitution is to ensure that the occurrence processes before and during the political decision making of sovereignty remain in the hands of the people without distortion and manipulation. In addition, as mandated in Article 28E Paragraph (3), Article 28F, and Article 28J Paragraph (2) of the 1945 Constitution, other legal products need to increase certainty in the application of the contents of the paragraphs mentioned in these articles. Hence, the issue of bot accounts is prominent to be established under the Indonesian law.

One option that can be taken to include bot account regulations in Indonesia is to enhance it into Law Number 19 of 2016 concerning Amendments to Law Number 11 of 2008 concerning Information and Electronic Transactions or the latest ITE Law through a revision process (Indonesia 2016). One of the main aspects that need to be included in bot account regulations is the obligation to publicize the status of bot accounts as bot accounts on social media. In that case, the regulation may not only be mandatory for users but also to social media companies located in Indonesia. To further eliminate the incentive to abuse bot accounts, breaches of the obligation to publicize the status of bot accounts as bot accounts can be sentenced through both civil and criminal procedures. This regulation is easier to consider for inclusion because the parameters are more objective and relatively easier to debate in court hearings. Aside from that, to encourage incentives for public oversight, one of which can be achieved by providing a portion of the fines that must be paid by the defendant through civil or criminal procedure to the party whose report is verified during a trial in court. 
The next aspect of bot accounts that can be included in Indonesian law is related to losses arising from activities that are proven to hinder the democratic process from running fairly. For example, prohibiting activities using systematic bot accounts to raise hashtags, spread disinformation, or attack particular parties. In order not to make a rubber article prone to abuse, the focus is placed on the systematic use of bot account activity. So, as long as they raise hashtags, spread disinformation, or attack particular parties without using a bot account, it will be left as another unregulated problem. However, the use of bot accounts for that purpose will be considered to hinders the democratic process. This need not to be confused with the law of using anonymous accounts, it is another matter that requires certain ethical considerations. Penalties for violations that obstruct the democratic process can be sentenced in the form of confinement or fines.

Moreover, special provisions are required in the use of bot accounts relating to the election of government officials. These distinctive provisions can be placed in the revision of the ITE Law or included in the revision of the Election Law. The contents of this distinctive provision relate to the consequences that must be faced for using bot accounts systematically to do things that hinder the democratic process with more severe penalties. To further reduce the incentive of bot account usage during elections with objectives mentioned above, the option of reducing votes can be carried out with calculations by presenting some expert witnesses who can provide objective information about them.

\section{CONCLUSION}

With 129.2 million active social media users, social media in Indonesia is one of the media used for political discourse that is full of polarization and disinformation. This polarization and disinformation process is the most widely disseminated in the context of cyberwar. Cyberwar itself in the context of social media refers to a cyber discourse battle to get a dominant position in political discourse through various instruments ranging from spreading propaganda to attacks on personalities aiming to hit the opponent's psychological condition or to win support from the wider community coverage. Bot accounts, which are accounts on social media that are controlled both by the content and behavior of certain software programs, are used as instruments of the cyberwar.

Although a bot account is considered as a tool, it is neutral in its nature. Its use within the industry is mostly aimed at cyberwar purposes, sharpening polarization and disinformation. These bot accounts are used both to spread the advocacy to support a stronghold, attack the opponents, and sharpen disputes between conflicted parties. As a result, the existence of bot accounts is detrimental to the deliberative democratic process from various sides. The first side is that bot accounts manipulate public communication so that what is being discussed is not what the public wants, but what one party who has access to the use of bot accounts desires. 
The information disseminated by bot accounts is supported by existing social media algorithms, which allow many people to receive partial information according to their preferences in life. Therefore, the composed reality is not comprehensive, and it is as if the opposing party's activities always make them lose and feeling threatened. Later on, the existence of bot accounts also undermines the diversity aspect in deliberative democracy. The use of bot accounts makes many voices that do not have access to bot accounts must be displaced. As a result, the existence of groups with minority identities will be neglected in the deliberation process. With bot accounts, the most emerging and developing opinions only occur in two extreme positions.

One option that can be taken to include bot account regulation in Indonesia is to regulate it either under Law Number 19 of 2016 concerning Amendments to Law Number 11 of 2008 concerning Information and Electronic Transactions or the latest ITE Law through a revision process. One of the main aspects that need to put into the regulation of bot accounts is the obligation to publicize the status of bot accounts as bot accounts on social media. The next aspect of bot accounts that can be added into Indonesian law is related to losses arising from activities that are proven to hinder the democratic process running fairly. For example, prohibiting activities using systematic bot accounts to enlarge hashtags, spread disinformation, or attack particular parties. In addition, special provisions are required in the use of bot accounts related to the election of government officials. These distinctive provisions can be placed in the revision of the ITE Law or added into the revision of the Election Law. The content of this distinctive provision relates to the consequences that must be faced for using bot accounts systematically to do things that hinder the democratic process with more severe penalties.

\section{REFERENCES}

Abdulsalam, H. (2018). Dari Bot ke Cyber Army: Mengorganisasi Hoaks di Media Sosial. Tirto. https://tirto.id/dari-bot-ke-cyber-army-mengorganisasi-hoaks-dimedia-sosial-cFwY

Al-Fatih, S., Aditya, Z., Haris, H., \& Kurniawan, W. (2019). ASEAN Civil Society In The Digital Era; Are We Moving Backwards? 317(IConProCS), 266-269. https://doi.org/10.2991/iconprocs-19.2019.55

Ansari, C., Hadil, S., Susetyo, K., Triyanto, A., Pujicahyono, B., Djunaidy, F., ... Nurtaqwa, Y. (2016). Penetrasi \& Perilaku Pengguna Internet Indonesia. Jakarta Pusat.

Arianto, B. (2020). Salah Kaprah Ihwal Buzzer: Analisis Percakapan Warganet di Media Sosial. Jurnal Ilmiah Ilmu Pemerintahan, 5(1), 1-20. https://doi.org/10.14710/jiip.v5i1.7287

Athallah, R. A. (2019). Memanipulasi Publik Lewat Akun Bot Twitter.

Bradshaw, S., \& Howard, P. N. (2019). The Global Disinformation Order: 2019 Global Inventory of Organised Social Media Manipulation. Oxfor. 
Dahl, R. (1991). Democracy and Its Critics. https://doi.org/10.7312/grau91070-013

Fahmi, I. (2019). Perang Robot Kubu 01 vs 02_ \#VisiMisijokowiMenang vs \#HaramPilihPemimpinIngkarJanji.

Ferrara, E., Varol, O., Davis, C., Menczer, F., \& Flammini, A. (2016). The rise of social bots. Communications of the ACM, 59(7), 96-104. https://doi.org/10.1145/2818717

Firmansyah, M. A., Mulyana, D., Karlinah, S., \& Sumartias, S. (2018). Kontestasi Pesan Politik dalam Kampanye Pilpres 2014 di Twitter : Dari Kultwit Hingga Twitwar. Jurnal Ilmu Komunikasi, 16(1), 42-53.

Fishkin, J. S. (2014). Deliberative Democracy in Context: Reflections on Theory and Practice. In K. Grönlund, A. Bächtiger, \& M. Setälä (Eds.), Deliberative MiniPublics: Involving Citizens in the Democratic Process. Colchester: ECPR Studies.

Hage, J. (2011). The Method of A Truly Normative Legal Science. In M. Van Hoecke (Ed.), Methodologies of Legal Research (1st ed., pp. 19-44). https://doi.org/10.5040/9781472560896.ch-005

Hellden, E., \& Gulliksen, J. (2017). A New Threat to Democracy? Examining the Democratic Implications of the Social Bot Phenomen. Lund University.

Karlsson, C. (2003). Den deliberativa drömmen och politisk praktik Samtalsdemokrati eller elitdiskussion. In M. Giljam \& J. Hermansson (Eds.), Demokratins Mekanismer. Malmo: Liber.

Lee, K. (2019). Your Honor, on Social Media: The Judicial Ethics of Bots and Bubbles. Nevada Law Journal, 19(3), 789-822.

Madison, S. (2017). How Social Media Has Changed the Way Political Movements Organize.

Nurul, A., Nurhadi, \& Pranawa, S. (2020). Konflik dan Ujaran Kebencian di Twitter. Jurnal Pendidikan Ilmu-Ilmu Sosial, 12(1), 132-142. https://doi.org/https://www.researchgate.net/deref/http $\% 3 \mathrm{~A} \% 2 \mathrm{~F} \% 2 \mathrm{Fdx}$.doi. org $\% 2$ F10.24114\%2Fjupiis.v12i1.16083

Soebakir, D. R., Pratama, B. I., \& Hair, A. (2020). Pemetaan Meme Politik Pasca Pemilihan Umum Presiden Indonesia 2019. Jurnal ILMU KOMUNIKASI, 8(2), 58-66. https://doi.org/10.21070/kanal.v8i2.220

Syahputra, I. (2017). Demokrasi Virtual Dan Perang Siber Di Media Sosial: Perspektif Netizen Indonesia. Jurnal ASPIKOM, 3(3), 457. https://doi.org/10.24329/aspikom.v3i3.141

Tucker, J. A., Guess, A., Barberá, P., Vaccari, C., Siegel, A., Sanovich, S., ... Nyhan, B. (2018). Social media, political polarization, and political disinformation. In William and Flora Hewlett Foundation. https:/ / doi.org/10.2139/ssm.3144139

Zainal, F., \& Megasari, N. F. (2019). Mempolitisasi Ruang Virtual: Posisi Warga-Net 
dalam Praktik Demokrasi Digital di Indonesia. Jurnal Ilmiah Manajemen Publik Dan Kebijakan Sosial, 306(1), 306-326.

https://doi.org/10.25139/jmnegara.v3i1.1459 